\title{
2
}

\section{The Starting Point: A Small Country, but a Major Maritime Nation}

Norway is larger than anyone knows:

Every ship, under the waving flag,

On the endlessly empty sea

Is a new part of Norway adrift ${ }^{1}$

At the start of the 20th century, the sentiment of the Nordahl Grieg poem quoted above undoubtedly rang true: Norway and its flag was everywhere. The country's ships were anchored in or voyaging between ports all over the world, facilitating the growth of commerce and enabling the formation of a truly international economy. Through ships, sailors and shipowners, this small country on the outskirts of Europe reached very far.

Norway had the world's fourth largest merchant marine, trailing only supremely dominant Great Britain — with around half of the world's seaborne transport capacity-Germany and The United States. Around 6.6 per cent of the sailing fleet and 3.6 per cent of the steamship fleet were flying the Norwegian flag.

${ }^{1}$ Grieg 1922, “The Flag” from Rundt Kap det gode Haab, author's translation. 
Shipping had continued to increase in importance after Kiær made his international comparison a decade earlier. Norway's merchant marine amounted to 1227 tons per 1000 inhabitants—so the "average" Norwegian actually owned more than one ton of shipping tonnage. Consequently, the shipping capacity per capita was high-much higher than the UK in second place, more than three times higher than Denmark in third place and more than four times higher than fourth-placed Greece. In other words, no country had put such a large share of its investments in ships. ${ }^{2}$ No country depended as much on shipping.

Table 2.1 provides an overview of the world's merchant marine and the seaborne trade volume of the most important participants in the international economy in $1900 .{ }^{3}$ The left side of the table shows the size of the fleets; the sailing fleet, the steamship fleet and the total tonnage. The column "effective tonnage" is the best measure of the carrying capacity of the fleet; here the figures have been adjusted to account for the higher productivity of steam vessels. Britain clearly dominated the oceans, with more than half of the steamships and more than 48 per cent of the "effective" world fleet.

The column "seaborne trade" shows the seaborne exports and imports of the various countries. Great Britain was in the lead here as well, with a demand for transport that was higher than the sum of the next two countries, the United States and France. However, the country's hegemony within world trade was on the wane-slightly less than 24 per cent of the total shipping demand was accounted for by British trade. ${ }^{4}$

\footnotetext{
${ }^{2}$ See Table 2.1 for sources. There is a theoretical possibility that another country might have had a higher relative share of its investments in shipping (for instance if total investments were much lower than in Norway). However, based on what we know about the economic structure of the countries at the time, the claim that Norway had put the highest share of its investments in ships is undoubtedly true.

${ }^{3}$ Table 2.1: Statistics Norway (1902a), Tables I and K, 168-169. Based on vessels above 50 tons, 31 December 1900. Tonnage figures for Russia refer to 1895, and do not include ports on the Caspian Sea and the Pacific, while the tonnage figures for Italy refer to 1898. US tonnage figures refer to 30 June 1900. British American seaborne trade refers to Canada, and British Australian to Victoria and New South Wales. Tonnage per capita refers to estimated tonnage, where one steamship ton is equal to 3.6 sailing ship tons. For a more precise description of the data behind the shipping movements, which include vessels in ballast, see the original source, Table K.

${ }^{4}$ Refers to the countries included in the sample in Table 2.1. In 1874 the British share of the world fleet had been more or less identical to this, but the share of world trade was higher. On the relationship between merchant marines and trade, see Ojala and Tenold (2017).
} 


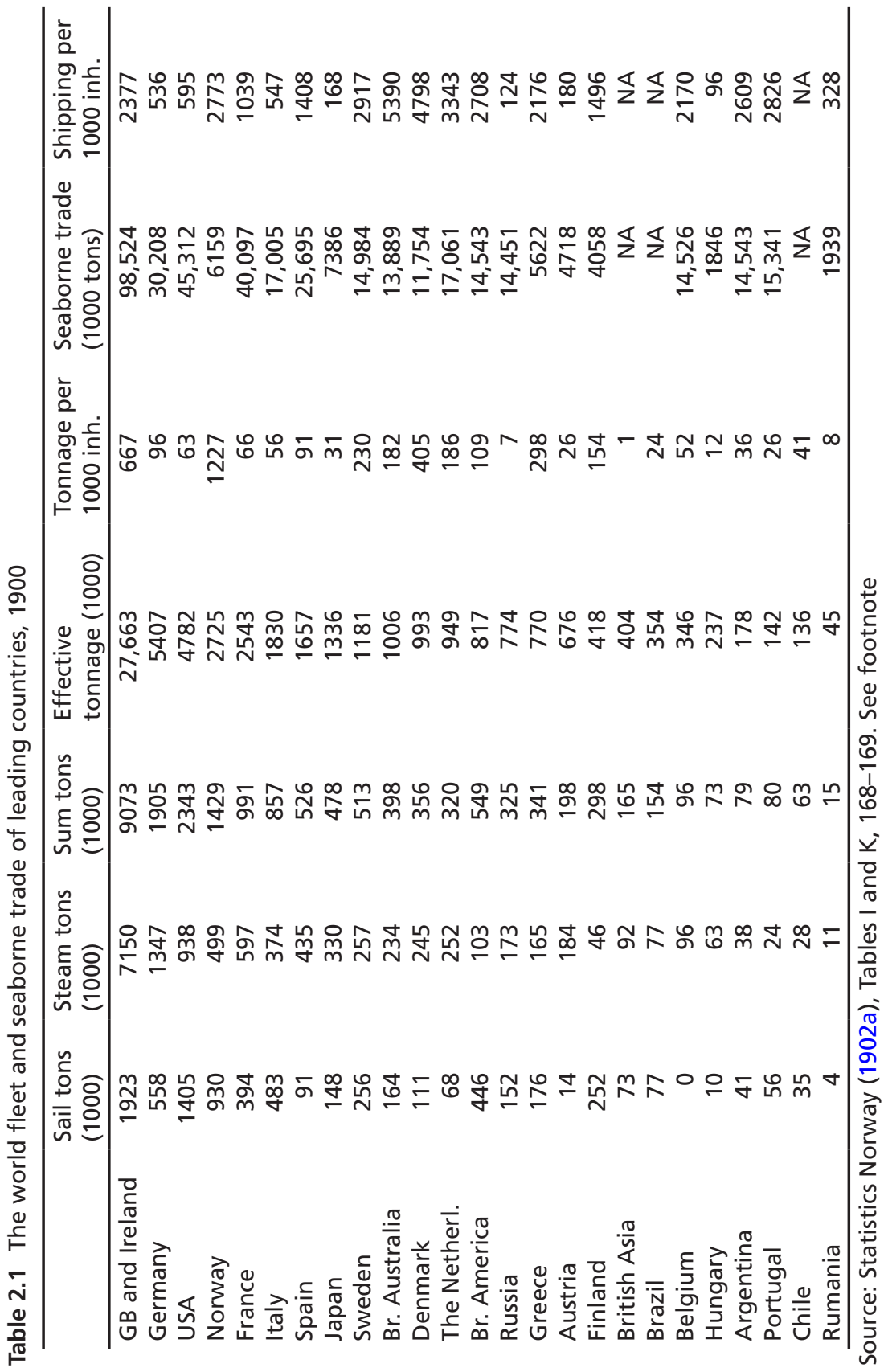


The fact that Great Britain had 48 per cent of the tonnage and 23 per cent of the seaborne trade movements suggests that Britain's fleet exceeded the country's shipping needs by a factor of more than two. In other words, more than half the shipping services it produced was "exported" and took place between other countries. This makes sense when we consider the manner in which British shipping lines served ports, particularly Empire ports, all over the world. The only country with a larger surplus of shipping capacity relative to its own trade was Norway, which was 16th of the countries with regard to the volume of seaborne imports and exports, but fourth with regard to the size of the fleet. ${ }^{5}$

To illustrate how the world had been divided into countries that performed shipping services for others, and countries whose trade was transported on foreign keels, we can consider a hypothetical world where shipping services were not traded internationally. If the ships only carried the countries' own seaborne trade, each Norwegian "ship ton" would transport 2.26 tons of cargo annually, while each British "ship ton" would carry 3.56 tons of cargo. ${ }^{6}$ At the other end of the scale we find Portugal where, if the country's trade was transported solely on Portuguese ships, each "ship ton" would have to carry more than 100 tons of commodities on an annual basis.

By 1900 the Portuguese depended upon ships from other nations-for instance Norway - to carry their cargoes. That year, 187 Norwegian ships called on Portugal, and only one Portuguese ship came to Norway. Less than 10 per cent of the Norwegian ships that went to Portuguese ports came directly from Norway-more than 170 ships were involved in the trade between Portugal and other countries. ${ }^{7}$

\footnotetext{
${ }^{5}$ A caveat: the volume of seaborne trade in itself does not determine the need for shipping capacity. In order to fully find a country's actual "transport demand," the distance that the cargoes are transported must be taken into account as well. Thus, the almost 14 million tons of Australian exports and imports - much of it going to or coming from Europe and the Americas-led to a higher demand for tonnage than the around 17 million tons of Italian seaborne trade-much of it transported in vessels pottering about in the Mediterranean or on short voyages to other European countries.

${ }^{6}$ The "world average" would be 7.4 tons of cargo per ship ton, based on the countries where we have data for both fleet and shipping. Six countries-in addition to Norway and the UK, Japan, Germany, Austria and Greece-were below the world average, and can be considered "theoretical net exporters of shipping services." Of course, a lot of confounding factors imply that this calculation is imprecise. However, it can at least give us an indication of the countries that had large fleets relative to their trade, and vice versa.
}

${ }^{7}$ Statistics Norway (1902b, 54-55 and 25). 
The Portuguese example illustrates that maritime hegemony is not permanent. The Iberian country that four centuries earlier had become famous for its first-class explorers, whose exploits were based on superior technology and outstanding nautical knowledge, had become insignificant in international shipping by the start of the 20th century. Indeed, four Norwegian cities-Bergen, Kristiania, Tønsberg and Stavanger-had larger fleets than Portugal. The Bergen fleet alone was more than four times larger than the Portuguese merchant marine. The descendants of Henry the Navigator had clearly lost their course.

The Norwegian ships, on the other hand, were all over the place, serving the needs of world trade. Although sailing ships had gradually been squeezed out of most short-distance trades by the more efficient steam vessels, Norwegian sailing ships remained competitive in certain market segments; copra from the Pacific, wheat from the Americas, coal from Australia and guano and nitrates from the western coast of South America. Here, voyages were long, and there was little reason to pay a premium for speedy transport of such cargoes, so the sailing ship technology was still viable. Moreover, ships make money when they are carrying cargo from A to $B$, not when they are lying still. In ports with inferior facilities, where loading and unloading was cumbersome and slow, it made economic sense to have an old, cheap sailing vessel lying idle for months, rather than a modern and expensive steamship.

While some owners had found niches that suited their old sailing ships, others operated at the diametrically opposite end of the market, focusing on modern vessels and shorter distances. Bergen-based steamship owners held such a strong position in the US fruit trade that questions had been asked in the US Congress about the Norwegian dominance. ${ }^{8}$ In East and Southeast Asia Norwegian ships found favour with local customers, as they were seen as less intrusive and threatening than those of the leading colonial powers, the UK, Germany and France. ${ }^{9}$

To illustrate the manner in which the Norwegian fleet was utilizedwhere the Norwegian ships were engaged—we can look at two different

${ }^{8}$ New York Times, 08061894,5 . Of the 63 ships included in a survey of the fruit trade, 37 were Norwegian.

${ }^{9}$ See Brautaset and Tenold (2010). 


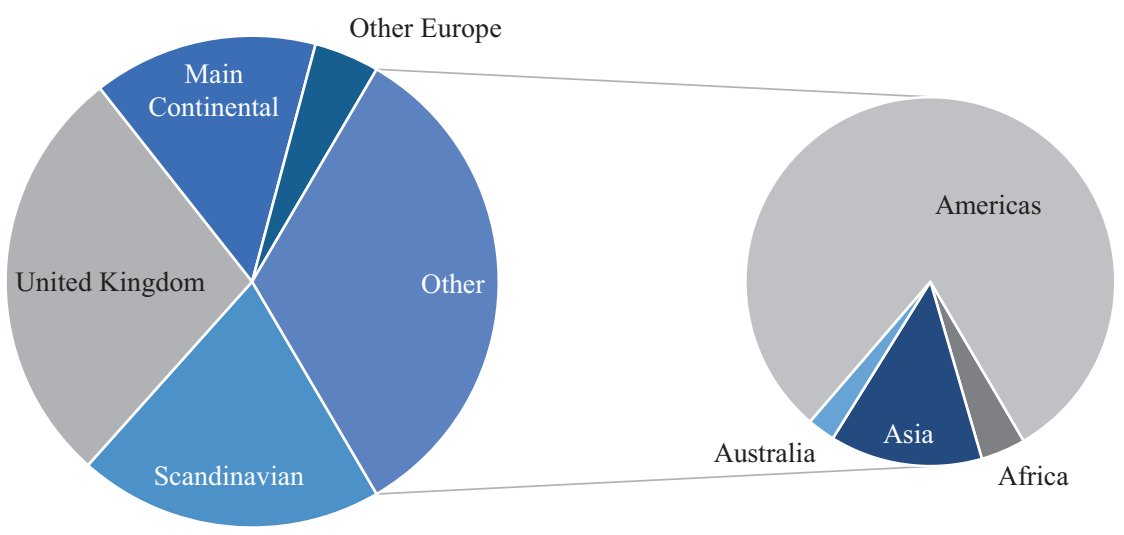

Fig. 2.1 Norwegian foreign-going shipping 1900, by country and region, per cent. (Source: Statistics Norway (1902a), Table 55, 73. See footnote)

sources from the start of the century. The first is the official Norwegian statistics, while the second is the voyage information provided by Lloyd's List. The quality of the contemporary Norwegian statistics is considered particularly high in an international perspective, reflecting the fact that Anders Nicolai Kiær, the Director of the Central Bureau of Statistics, since 1869 had been given a "special responsibility" for the compilation, coordination and comparison of international shipping statistics. ${ }^{10}$

Norwegian ships had a market share of around two-thirds in the country's own imports and exports. The most important competitors were British ships - carrying slightly more than 10 per cent of Norway's foreign trade-followed by Danish, Swedish, German and Russian/Finnish ships. ${ }^{11}$ The home trade—slightly more than 4 million tons_-only made up around one-eighth of the volumes carried by Norwegian ships. ${ }^{12}$ In other words, more than 87 per cent of "the production" took place between foreign ports. ${ }^{13}$ Figure 2.1 gives an indication of the most impor-

\footnotetext{
${ }^{10}$ See Lie and Roll-Hansen (2001), Bjerkholt and Skoglund (2012, 22-27) and Kiær (1876-1892).

${ }^{11}$ Calculated on the basis of Statistics Norway (1902a, 70). Perhaps surprisingly, the share is more or less identical regardless of whether we include vessels arriving and leaving in ballast.

${ }^{12}$ See Fig. 2.1 for details. The figure differs from that in Table 2.1, where ballast movements were included.

${ }^{13}$ Statistics Norway (1902a, 73).
} 
tant markets - though again, it is important to remember that the effect of sailing distance is not taken into account.

Figure 2.1 shows that around two-thirds of the cargoes that the ships carried came from or were bound for Europe. ${ }^{14}$ With more than a quarter of the entries and exits, the UK was the single biggest market for Norwegian ships, reflecting the crucial role that the British Empire played in international trade around the turn of the century. Interestingly, Norwegian ships transported more cargoes to and from "the Americas"North, Central and South America-than to and from Scandinavia.

Revenue-wise, Britain also appeared to be in the lead, with gross freight earnings of more than NOK73 million, as shown in Fig. 2.2. ${ }^{15}$ Earnings from the American market were only marginally smaller, at NOK69 million, but were in fact more important. The reason for this is the manner in which the business was conducted: many of the ships trading on the Americas operated on time charters, where the Norwegian owners did not have to pay bunkers and port costs. ${ }^{16}$ So, when it comes to the amount

\footnotetext{
${ }^{14}$ Figure 2.1: Data refer to total tonnage and are taken from Statistics Norway (1902a), Table 55, 73. The statistics are based on the tonnage of the ships cleared, rather than the weight of the cargo. While ships in ballast are reported separately, but included in these figures, the statistics are not adjusted to reflect ships that are not fully laden. There are some missing reports in the data, see Statistics Norway (1902b), Tables 18-20, 54-81. Given that vessels are registered both on their ingoing and outgoing voyage, their transported volumes are counted twice, but this has a minimal impact on relative shares.
}

The groups include the following categories from the statistics:

Scandinavia: Norway, Sweden and Denmark (including Iceland and the Faroe Islands).

UK: Great Britain and Ireland.

Main Continental: Germany, the Netherlands, Belgium, France, Portugal and Spain.

Other Europe: Russia/ Finland; Italy, Malta and Austria-Hungary; and Turkey, Rumania and Greece.

The Americas: North America; West Indies, Mexico and Central America; South America.

${ }^{15}$ Figure 2.2: Data refer to ingoing and outgoing laden tonnage, excluding vessels in ballast, and are taken from Statistics Norway (1902a), Table 55, 73. There are some missing reports in the data, see Statistics Norway (1902b), Tables 18-20, 54-81. Given that vessels and revenues are registered both for the ingoing and outgoing voyages, transported volumes and gross freight earnings are double-counted. The category "adjusted gross freight earnings" includes vessels operating on time charters, and are not included in the data presented in Statistics Norway (1902a), Table 55, 73.

Groups are the same as in Fig. 2.1.

${ }^{16}$ Almost 40 per cent of the earnings in the Americas were reported after coal and port costs had been deducted, compared with less than 10 per cent of the British earnings. In the trades on Japan and China, practically all of the earnings - more than 99 per cent-have been categorized as timecharter revenues in the statistics. 


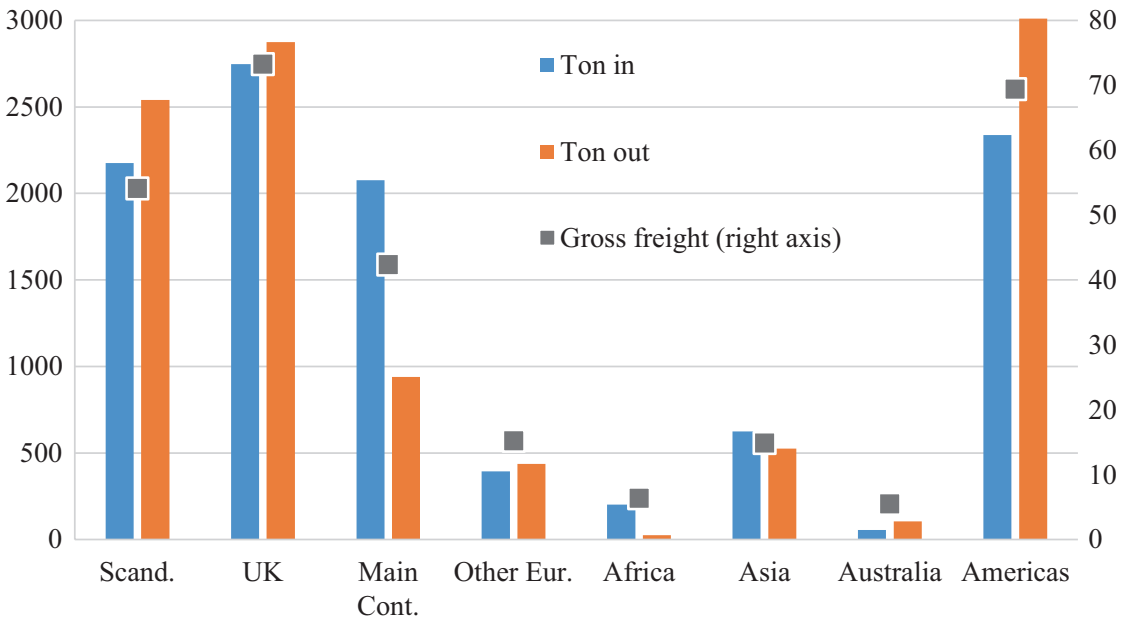

Fig. 2.2 Shipping volumes (1000 grt, left axis) and freight revenues (million kroner, right axis) 1900. (Source: Statistics Norway (1902a), Table 55, 73. See footnote)

of money that was returned to Norwegian sailors and investors, the most important market at the start of the 20th century was the Americas, particularly the United States, which was responsible for two-thirds of the gross freight earnings from that region.

The gross freight earnings do not show profits, as they usually do not take into account the costs accrued abroad when "producing" the transport service. Operating costs were typically higher for steamships than for sailing ships, due to their appetite for coal. However, there were substantial variable costs for sailing ships as well-although the wind was free, sailors had to be paid and fed, and ropes and sails had to be maintained, and were changed with surprisingly high frequency.

The tonnage data in Fig. 2.2 do not include ships travelling "in ballast" - ships that were sailing from one port to another without revenuegenerating cargoes. Differences between ingoing and outgoing volumes thus reveal the disequilibria in the trade of the various parts of the world. Continental Europe and Africa, in particular, had much larger volumes entering than going out, while there was an export surplus, volume-wise, from Australia and the Americas. 
Thanks to A.N. Kiær's insatiable appetite for shipping statistics, we also have data that can illustrate the differences between various types of vessels. Table 2.2 provides a snapshot of the differences in efficiency and revenue between sailing ships and steamships at this point more or less midway through the transformation from sail to steam. ${ }^{17}$

It may seem surprising that the revenue per ton transported was more than NOK19 for the sailing ships, compared with NOK11 for the steamships. Two factors can explain this. First, we know that sailing ships transported their cargoes relatively far, which is not captured when a simple ton measure is used as the basis. Second, the difference in efficiency between the two ship types shines through; the average steamship transported more than 10 times as much cargo in a year as the average sailing ship. Even though the sailing fleet was almost twice as large as the steamship fleet, the latter transported more than three times as much. Gross freight earnings per ship were more than six times higher for steamships, and in 1900 each "steamship ton" earned 186 kroner, compared with 55 for each "sailing ship ton." 18

The data above provide information about where the Norwegian ships were employed and suggest some differences between regions and vessel types. Although the Norwegian statistics inform us about the countries that were visited, they only include a single locational marker for each voyage-either country of departure or country of arrival. In order to understand both where ships came from and where they were going, as well as the importance of individual ports, we can turn to the British periodical Lloyd's List. With London still very much the centre of world transport and commerce, Lloyd's List provided producers, charterers, traders, brokers and others involved in the shipping industry with news and information.

\footnotetext{
${ }^{17}$ Table 2.2: Information on number and gross register tonnage (grt) from Statistics Norway, 1901, Table 35, 51. Based on vessels listed as part of the foreign-going fleet, 31 December 1900. Information on volumes and revenues from Statistics Norway (1902a), Table 55, 73. To avoid double counting, volumes and gross freight earnings are estimated as the average of inward and outward volumes and values.

${ }^{18}$ Higher variable costs would offset some of the steamship profits. The differences between estimates per ship and per ton are accounted for by the fact that the steamships in this part of the fleet were on average 85 per cent larger than the sailing ships: 670 versus 361 tons.
} 


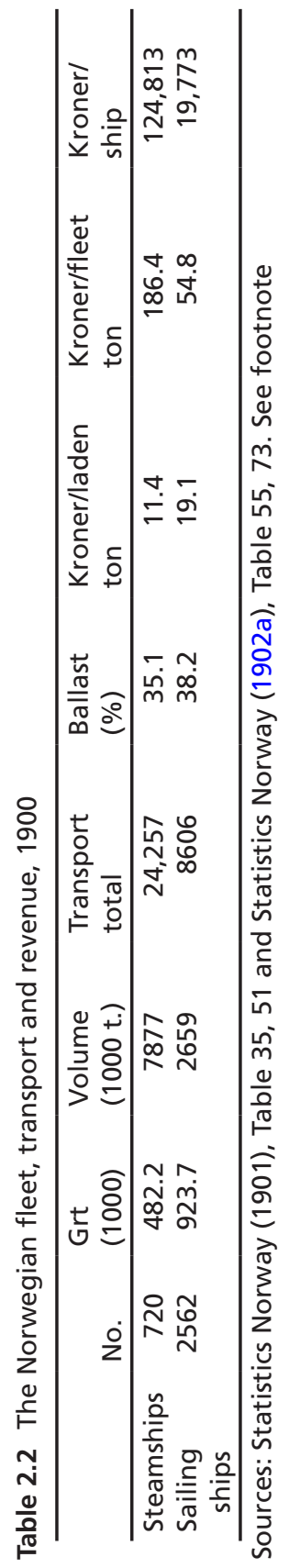


Table 2.3 Norwegian ships' most important port calls and voyages around the turn of the century

\begin{tabular}{llclc}
\hline & & \multicolumn{2}{c}{ Per cent of } & Per cent of \\
& Port & calls & From-to & $\begin{array}{c}\text { voyages } \\
\text { vow York }\end{array}$ \\
\hline 1 & New & Cardiff-Vera Cruz & 0.4 \\
2 & Liverpool & 3.3 & Cardiff-Pernambuco & 0.4 \\
3 & Cardiff & 3.0 & Cardiff-Bahia & 0.3 \\
4 & London & 2.8 & Quebec-London & 0.3 \\
5 & Hamburg & 2.1 & Laguna-Hamburg & 0.3 \\
6 & Pensacola & 1.9 & London-Quebec & 0.3 \\
7 & Buenos Aires & 1.7 & Trapani-Stavanger & 0.3 \\
8 & Quebec & 1.6 & Hamburg-New York & 0.3 \\
9 & Savannah & 1.5 & Pensacola-Buenos Aires & 0.3 \\
10 & Rio Janeiro & 1.3 & New York-Stettin & 0.2 \\
11 & Newport & 1.2 & Belize-Goole & 0.2 \\
12 & Philadelphia & 1.2 & Cardiff-Maranham & 0.2 \\
13 & Clyde & 1.1 & New York-Hamburg & 0.2 \\
14 & Table Bay & 1.0 & Cadiz-Rio Grande & 0.2 \\
15 & Marseilles & 1.0 & Liverpool-Halifax & 0.2 \\
\hline
\end{tabular}

Source: Lloyd's Weekly Shipping Index, various issues, 1882, 1892 and 1902. See footnote

Ports all over the world were regularly visited by Norwegian ships, captains and crews, but Table 2.3 illustrates that some were more important than others. ${ }^{19}$ The high concentration of world trade is evident- the 12 most important ports made up more than a quarter of all port calls in the data from Lloyd's. But Norwegian ships of course travelled to more exotic locations as well. In the decades around the turn of the century, they were registered in at least 1200 different foreign ports, according to

${ }^{19}$ Table 2.3: Lloyd's Weekly Shipping Index, various issues, 1882, 1892 and 1902. Lloyd's Weekly Shipping Index compiles listings from the Lloyd's List daily, and for simplicity, Lloyd's List is referred to in the text. Based on a purpose-built database of 9660 voyages by Norwegian vessels in 1882, 1892 and 1902. For each vessel listed in Lloyd's Weekly Shipping Index, two random voyages-one in the first half of the year and one in the second-have been selected. See Brautaset and Tenold (2010, 203-222) for more detailed information about the database. Due to the nature of the material included in Lloyd's Weekly Shipping Index-it records "all mercantile vessels on ocean voyages", but with some exceptions - ships trading locally in Europe are likely to be underreported. This refers primarily to sailing vessels "on voyages from one port to another in the Continent of Europe, between the White Sea and Cape Finisterre" and "between the UK and ports on the Continent as far south as Cape Finisterre", as well as steamships "trading between the UK and ports on the Continent, between the Scaw and Loire" and "trading between ports on the Continent between the North Cape and the Loire." 
Lloyd's List. ${ }^{20}$ Places such as Nash Creek in New Brunswick, Canada (population: 150), with a post office, a store and a factory specializing in the production of doors and doorframes, were clearly a contrast to the New York or London metropolises. ${ }^{21}$

The voyages listed above were the most frequent ones for Norwegian vessels. To some extent, they reveal the Norwegian specialization; transport of bulky cargoes from British coal ports and North American timber ports. The highways of the seas, where the infrastructure was good, the traffic density was high and the conditions were usually predictable, were less important for the Norwegians. Many of these passages were dominated by the large liner conferences, where the mighty British, American and Continental shipping companies colluded to reserve cargoes and ensure high freights. The voyage Paspébiac-Llanelly does not have the same ring as New York-Liverpool, but Norwegian ships could not afford to discriminate. ${ }^{22}$ They travelled everywhere-from Aalborg to Zarate; from Wuhu to $\mathrm{Ha} \mathrm{Ha} \mathrm{Bay}^{23}$

This snapshot of Norwegian shipping in 1900 shows a small country that is clearly "punching above its weight" in the international shipping industry. In the 1870s Norway had the third largest fleet in the world; by 1900 the country had been relegated to fourth place. But in no other country had local investors put so much of their resources into oceangoing ships. How can the strong position that shipping held in Norway, and the country's central role in the international shipping market, be explained?

\footnotetext{
${ }^{20}$ This figure is likely to be underreported. Information from smaller ports was less likely to get to London and the compilers of the Lloyd's List in time. Moreover, the publication did not report extensively about smaller ports on the European continent; see the note to Table 2.3. The economic historian Jan Tore Klovland, who has meticulously collected information on more than 200,000 voyages from the period 1835-1920, has more than 2400 different ports listed in his material. It is likely that the majority of these were visited by Norwegian ships.

${ }^{21}$ Information on Nash Creek from the Provincial Archives of New Brunswick.

${ }^{22}$ And it was a dangerous trip. Captain Hansen's barque Pons Aelli, the only Norwegian ship registered between these two ports in 1902, had to be abandoned in the middle of the ocean.

${ }^{23}$ Aalborg (Denmark) and Zarate (Argentina) were quite common destinations. However, the data set contains only one observation each for Wuhu (China) and Ha Ha Bay (Newfoundland).
} 


\section{Why Norway? Geography, History and Culture}

At the start of the 20th century, three fundamental features combined to explain how this small country had managed to become one of the world's leading maritime nations; geography, history and culture. The land and the sea shaped experiences, and experiences influenced values and attitude. The result was Norway, the maritime nation.

The first factor that can explain the Norwegian advantage in international shipping is geography. Without resorting to environmental determinism, it is evident that the sea and its firm grip on the coast and its inhabitants implied that Norway was destined to become a maritime nation. In fact, the name of the country - the Norðvegr-refers to a protected sailing route along the coast, it is "the way to the north." Thus, whereas the names of other countries usually refer to the territory on land and the people living there-Francia, Scotland and Denmark-even the name Norway refers to the sea and to movement. ${ }^{24}$

The shape of the country implied that the sea was a much more important means of communication and transport than the land. The topographical conditions - the high mountains that separated the fjords and the modest settlements along the coast-forced Norwegians to take to water and undoubtedly played a decisive role in the development of maritime know-how and their orientation towards the sea. Water provided the most important means of transport and was a significant source of supplies. The geography in the coastal areas had created the archetypal Norwegian sailors - the Vikings. Their ability to build advanced ships, their navigational skills and seamanship, as well as their outward orientation-all were features that we can see traces of in Norway in the 19th and 20th centuries. We see these traces, not due to an unbroken line from Viking exploits to modern Norwegian shipping, but because the geography that promoted and honed these skills remained constant.

During the 20th century, telecommunications, airplanes, cars, trucks and high-speed trains have revolutionized human interaction. However, to understand the role of the sea, it is important to remember that these

\footnotetext{
${ }^{24}$ Skre, Dagfinn (2014, 34-44). This is of course the opposite of nominative determinism; the country got its name because it represented the way to the north.
} 
are new phenomena. Well into the 20th century, water bound people together, while land separated them. Water transport was the least costly and most efficient way of carrying cargo and people, and maritime skills thus became a means for economic and cultural survival in a country such as Norway. The sea connected markets and districts, while dry land-mountains, in particular, but also forests-kept communities apart.

Norway was a relatively large country size-wise-it has the longest coastline in Europe-but had a fairly limited agricultural resource base and low population density. ${ }^{25}$ This encouraged the people to trade with others in order to get vital supplies; a domestic surplus of fish and wood was exchanged for necessities such as grain and textiles from Continental Europe. Much of this trade had been performed by vessels from the German Hanse and subsequently from the economically and politically advanced Dutch Republic. By the middle of the 17th century, Bergen was the only Norwegian city that had been able to build up a substantial merchant fleet; in 1640 it amounted to 3500 lasts and locally owned ships transported 40 per cent of the city's trade. ${ }^{26}$

The country's position - in the northern part of the European continent and cut off from vibrant markets - stimulated trade in general, and medium-distance trade in particular. The central role played by the sea, both in local communications and in the harvesting of resources, gave Norwegians an advantage in seaborne transport. Subsequently, in the 19th century, when markets were opened and international trade

\footnotetext{
${ }^{25}$ At 25,000 kilometres ( $\mathrm{km}$ ), Norway's coastline is the seventh longest in the world and longer than the coastlines of for instance the United States, New Zealand and China. According to data from CIA's World Factbook it is almost twice as long as that of Greece, which is second in Europe (not counting Russia and Greenland). Data from the Norwegian Mapping Authority suggest that the length of the coastline increases to more than $100,000 \mathrm{~km}$ when fords, bays and islands are included; Statistics Norway $(2015,6)$.

${ }^{26}$ Figenbaum et al. $(2009,7)$. A lest [last] was an old measure of the size of ships, in Norway usually measured in terms of barrels of grain (12) or coal (18). However, the "commercelæst" was defined in the statistics as a weight measure (equal to 5200 pounds) before 1846, and as a volume measure (equal to 165 cubic feet) after 1846; see Statistics Norway $(1948,238)$. With the transfer to the Moorsom measuring system in 1876 , a common means of translation was to set one last equal to around 2.1 net register tons. Almost half of the Norwegian sailings to the Baltic in the period 1575-1654, as registered in the Sound tolls, were by Bergen vessels. Around 1730 the city's monopoly in the trade on Greenland and Iceland was transferred to Copenhagen, reducing the need for tonnage.
} 
increased, this skill became a selling point in itself. Moreover, the fact that Norway was not a major power actually helped business abroad, securing market access due to the apparent lack of colonial pretensions.

There is another geographic factor worth noting: Norwegian shipping was a widely dispersed economic activity. The ownership of vessels engaged in international trade was not confined to a handful of industrious cities or trading towns, but spread all along the coast. There was the aforementioned concentration in the southern part of the country, as fishing was the favoured maritime activity further north. However, in the south, although sea transport primarily was an urban activity, numerous small communities along the coast and in the fords invested in tonnage and supplied seafarers for the international market.

This wide geographic dispersion of Norwegian shipping declined slowly. There was clearly a technological and financial element to the decline - in the first decades of the 20th century the ownership of expensive steam tonnage was primarily a city phenomenon, and showed much higher concentration than ownership of the more affordable sailing ships. In 1900 the three leading cities, Bergen, Kristiania and Tønsberg, controlled almost two-thirds of the steamship tonnage, while the three leading sailing ship ports, Kristiania, Arendal and Stavanger, controlled less than a quarter of the sail tonnage. Moreover, around 16.5 per cent of the foreign-going sailing ship fleet was registered in bygder [villages] along the coast. This was more than twice as high as the corresponding figure for steamships. ${ }^{27}$

Geography is intimately intertwined with the second reason for the strong Norwegian position in the shipping industry; history. The maritime dimension put its mark on the lives of the Norwegians: "In the history of the Norwegian people, the sea provides an eternally fluctuating course. Our national character and our culture have been determined by it, just like our political, social and economic life." ${ }^{28}$

Within Norway, the legacy as a maritime nation has always been very visible, even on shore; "in Western Norway [almost everybody] is a sailor.

\footnotetext{
${ }^{27}$ Based on Statistics Norway (1902b), Table 1, 3-9. See also Schreiner (1963, 14-19), for a discussion of the development in the period up until 1914.

${ }^{28}$ Egeland (1930, 3).
} 
The hotel porter has an anchor tattooed on both forearms; the taxi-driver and the waiter talk the uninhibited English that is the lingua franca of the sea." ${ }^{29}$ Statues and memorial plaques have been dedicated to courageous sailors, while streets, buildings, museums and galleries carry the names of prominent and generous shipowners.

The shipping industry is more present in Norwegian society than in practically all other European nations. ${ }^{30}$ Some shipowners have established wealthy foundations that donate money to art and research, while other foundations target social issues, providing support for seamen's widows, their surviving children or sailors "in economic difficulties." 31 Some shipowners are highly visible public figures, while others-ironically_are famous for their anonymity. Finally, a large number of people still work in the offices of shipping companies, maritime insurance and financing companies, in shipping banks, ship brokers and other related business, or are engaged in a variety of maritime activities. They are part of the maritime legacy, and continue to be an important economic reality.

But even history has to start somewhere, at some time. Norway's rise as a major maritime nation was a protracted and erratic journey, one that did not achieve sustained and rapid growth until the second half of the 19th century. After the Dutch lost their dominant position in the trade on Norway in the middle of the 17 th century, a specific pattern developed with regard to the advance of Norwegian shipping. When the major European powers - the UK, France, the Netherlands, Spain-were involved in wars, the Norwegian fleet increased. During periods of peace, or-even worse-when Denmark-Norway was involved in wars with their Nordic neighbour, the market share fell.

\footnotetext{
${ }^{29}$ The Norwegian Joint Committee on International Social Policy $(1959,20)$.

${ }^{30}$ Again, the exception would be Greece, where the maritime legacy also has a dominant position, in particular in Piraeus and on the islands. For a good introduction to the regional and family dimensions of Greek shipping, see Harlaftis and Theotokas (2004).

${ }^{31}$ In the early 1970 s, the book Norske sjømannslegater og stiftelser [Norwegian seamen's endowments and foundations] was around 250 pages long and contained information on more than 400 individual endowments by shipowners, consuls, captains and their wives. Fittingly, the book was published by a fund established by the Norwegian Shipowner's Association to honour the memory of Norwegian sailors during the First World War; see Norges Rederforbunds Sjømannsfond av 1918 (1973).
} 
The first half of the 18th century was a difficult period, and from 1696 to 1745 the size of the Norwegian fleet declined by almost two-thirds. ${ }^{32}$ Still, seaborne transport at this time was not the specialized activity that it is today. Rather, shipping was closely linked to local trading houses and most of the transport was related to Norwegian exports and imports. Luckily, from a shipping point of view, many of the commodities that were exported from Norway-forest products, fish and minerals, mainly copper and iron-were bulky cargoes that needed a lot of cargo space relative to their value. ${ }^{33}$

The extent of third-country shipping was limited in the first half of the 18th century. However, shipping activities increased immensely before Denmark-Norway was drawn into the Napoleonic Wars, with the number of ships and sailors almost trebling in the two decades after 1776; "the country's merchant marine saw a larger expansion within a few years than it had during a whole century." 34 The basis for the growth was a combination of political stimulus, high demand abroad - a well-known phenomenon also during subsequent wars-and low operating costs. ${ }^{35}$ According to a contemporary British source, the lower operating costs were a result of the fact that Norwegian sailors were "being paid a certain stipend for the voyage out and home, and not by the month (as is the custom [in Great Britain])." The effect of this incentive was clear; it "becomes in the interest of these foreigners to use every exertion in their power to accomplish the voyage in the shortest time possible." ${ }^{36}$ Even in the late 18th century it was not uncommon to blame workers in other countries for their high productivity...

\footnotetext{
${ }^{32}$ Denmark-Norway re-entered The Great Northern War in 1709. In the period 1710-1713, Bergen lost 55 ships, almost half of the pre-war fleet, to privateers (who were basically governmentsponsored pirates); see Dyrvik (1979, 107). In order to avoid privateers, ships could take to the sea when the sailing conditions were bad. This of course increased the probability of wrecking. When Denmark-Norway was involved in wars, Norwegian ships were sailing between a rock and a hard place.

${ }^{33}$ In the 19th century, another bulky cargo, ice, was added, and in the peak years around 1900 more than a million tons of ice was exported annually. Technological advances onshore-improved refrigeration and production of plant ice-led to a market meltdown, and the Norwegian ice exports had more or less dried up by the outbreak of the First World War.

${ }^{34}$ Schweigaard $(1840,131)$.

${ }^{35}$ Johansen (1992, 488-489).

${ }^{36}$ Quote from merchant's testimonial to a 1786 Board of Trade inquiry; Johansen $(1992,487)$.
} 
The majority of the new ships were built in Norway, particularly on the South Coast. ${ }^{37}$ Given current controversies in shipping, it is worth noting that in the first years of the 19th century, some of the vessels on the Norwegian register were owned by "foreigners, who by means of pro forma-documents enjoyed the advantage of our country's neutrality." 38 Thus, according to contemporary sources, Norway appears to have been an early example of a Flag of Convenience, enticing foreign owners by providing beneficial conditions. This was not the first time Norway was used to create a false sense of neutrality, but subsequent research has suggested that though the assertion is correct, the scale of this practice was limited. ${ }^{39}$

Again, Norway did well as long as the country stayed away from the conflict, but when Denmark-Norway was dragged into the war, there was little consolation in the Norwegian flag. In 1807, following the preemptive British bombardment of Copenhagen and the Danish-Norwegian entry into the war, more than 550 ships, as much as a third of the fleet, was lost. The effect on Norwegian shipping was devastating. In the subsequent years, British authorities continued to confiscate Norwegian ships, and by the end of the war more than 5000 Norwegian sailors had been put in prison in the UK, some for as long as seven years. ${ }^{40}$ Although Norwegian privateering partly balanced the picture, the British might at sea was too strong.

In the short term, the Danish-Norwegian participation on Napoleon's side in the conflict had dreadful effects; famine, un(der)employment, increasing mortality, economic decline, financial and monetary collapse- "one of the bleakest periods in modern history." ${ }^{41}$ In the longer term, the fact that Denmark was on the losing side, meant Norwegian freedom.

\footnotetext{
${ }^{37}$ Dyrvik (1979, 177). According to a survey of the pre-war fleet in Den Norske Rigstidende, 1 February 1815, 1 the three main shipbuilding areas were Arendal (174 ships), Bergen (170 ships) and Øster-Riisøer (Risør, 115 ships).

${ }^{38}$ Schweigaard $(1840,183)$.

${ }^{39}$ See for instance Kiær $(1893,333)$, or more detailed discussions in Thue (1980, 150-151), Tveite (1965) or Schreiner (1952).

${ }^{40}$ See for instance Berit Eide Johnsen's fascinating book on the cultural exchange that this entailed; Johnsen (1993).

${ }^{41}$ Eitrheim et al. (2016, 84-85).
} 
At end of the war, Norway's status as a Danish province ended after almost three centuries. ${ }^{42}$ Despite the introduction of a Norwegian constitution, the country's independence was very short-lived. In November 1814 the recently established parliament was forced to accept a union with Sweden. The attempt at full independence thus ended in futility and political compromise, and Norway became the "little brother" in a personal union with Sweden. In addition to the parliament and the constitution, Norway retained executive and judiciary powers, but the two countries shared the monarch-from the Swedish house of Bernadotteand the foreign policy was conducted by the Swedish Ministry of Foreign Affairs.

The change in union partner had a positive effect on the Norwegian foray into world shipping. In terms of international trade, SwedenNorway was not a minion. The countries exported large amounts of timber and wood; one of the most traded, and also most volume-demanding, commodities. Up until the middle of the 1820s Swedish timber exports were reserved for Swedish keels. Subsequently, as a result of an extension of Mellanrikslagen [the Interstate Laws] and the abolition of Produktplakatet [the Commodity Ordinance aka "The Swedish Navigation Act"], Norwegian ships were from 1825 allowed to compete on even terms with local ships in the transport of Swedish cargoes, for instance timber. ${ }^{43}$ With Swedish protectionism out of the way, the lower-cost Norwegian vessels became an attractive alternative for Swedish importers and exporters. The share of Norwegian ships in Sweden's trade increased from 4 per cent in 1819 to 34 per cent in $1849 .{ }^{44}$

This expansion of Norwegian shipping in the first half of the 19th century was not based on long-distance trades, but that soon changed. In a Parliamentary discussion on maritime skills in 1839 it was emphasized that "it is not common - but rather an exception - that our captains sail

\footnotetext{
${ }^{42}$ The Kalmar Union between Denmark, Sweden and Norway was formed at the end of the 14th century. Sweden finally withdrew at the start of the 16th century, and Denmark gradually strengthened its grip on its Norwegian partner.

${ }^{43}$ On the effects of the Navigation Acts in Scandinavia, see Ojala and Räihä (2017). A provisionary decree that abolished the restrictions was introduced in May 1825 and confirmed by a law in August 1827.

${ }^{44} \operatorname{Kiær}(1893,34)$.
} 
the distant seas." Consequently, the politicians saw the need for formal nautical education as limited. The reason was that the ships primarily operated in the North Sea- "at most extending to the Baltic" — where "experience to some extent can neutralize the lack of navigational knowledge." ${ }^{45}$ In the second half of the 19th century, this local, northern European focus became relatively less important. Again, the basis was primarily political, and again, the political decisions were not made within Norway.

The aggressive acquisition of market shares in Sweden in the 1830s and 1840 s was a prelude to what happened in the second half of the 19th century-though by then the backdrop was not just advances at the expense of a neighbour, but the lifting of restrictions on a global scale. After 1850 practically the whole world was opened up to Norwegian shipping, and the competence that Norwegian shipowners and sailors had built up became much sought after. The liberalization paved the way for a massive expansion of Norway's shipping interests.

In June 1849 Queen Victoria signed the Act that repealed the protectionist Navigation Laws, which had limited the participation of foreign ships in British trade and transport. At this time Great Britain was the centre of global commerce, and now the country opened its trade to ships of all nations. For Norwegian shipowners, the prey suddenly got much, much bigger, and the combination of low costs and high efficiency was a formula that triumphed in the British market. From 1850 to 1860 the Norwegian tonnage cleared in British ports increased by 191 per cent, and only the United States had a larger absolute increase in the transport of British trade. ${ }^{46}$ Freed from the limitations of Sweden-Norway's imports and exports, and no longer hampered by protectionist measures abroad, Norwegian shipping flourished.

\footnotetext{
${ }^{45}$ Norway, Parliament, Odelsthinget, 13071839, 679 and 685. The politicians' powers of prediction were no better in the 19th century than they are today. Less than 18 months after this discussion, the first Norwegian vessel rounded Cape Horn. Among the cargoes that the brig Preciosa carried was aquavit, a traditional Norwegian potato spirit. Even today, aquavit is transported on ships crossing the equator, where humidity, continuous movement and temperature changes affect the maturation and the final taste. Preciosa became so famous that the Norwegian poet Henrik Wergeland wrote a shanty specifically about the ship. See Nordlyset, 05071844, 3 and Blom (1977, 177-180).

${ }^{46}$ Glover $(1863,14)$.
} 


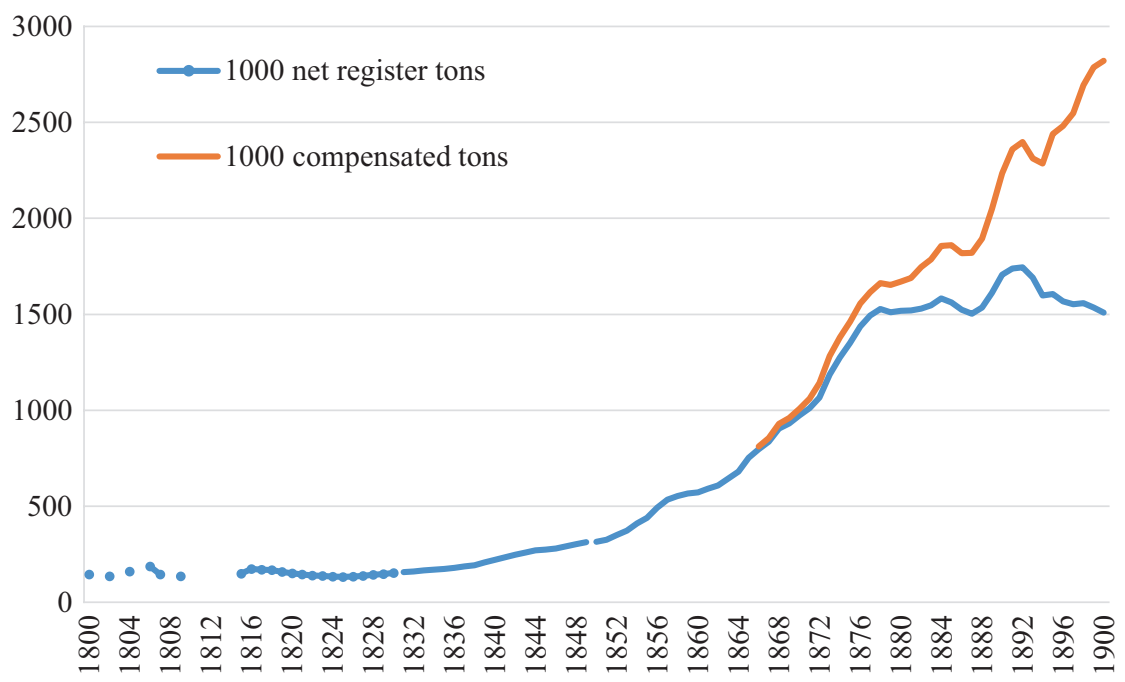

Fig. 2.3 Estimates of the Norwegian fleet, 1800-1900, 1000 net register tons. (Source: Statistics Norway (1949), Table 126, 241-242. See footnote)

The liberalization of the international market was a necessary condition for the enormous expansion that took place in the second half of the 19 th century. Figure 2.3 shows that the Norwegian fleet growth was characterized by strong fluctuations in the first decades of the 19th century, followed by a slowly upward-sloping trend from 1830 onwards. ${ }^{47}$ However, the expansion in the period 1830-1850 was uneven, characterized by two steps forward and one step back. ${ }^{48}$ From the middle of the

\footnotetext{
${ }^{47}$ Figure 2.3: For a good discussion of the problems of estimating the size of the Norwegian fleet in the 19th century, see Brautaset $(2002,118-128)$. Due to the considerations presented there, the data used here should be seen as a minimum, and are based on the following sources 1800-1809 from Dyrvik (1979, 177), 1815-1830 converted from the data in Commerselæster by the factor 2.1 from Kristiansen 1925; 1830-1865 based on Brautaset $(2002,258)$. Both of these sources have adjusted the official statistics, but refer to the full fleet, rather than the ships trading abroad; see also Broch $(1876,81)$. Data from the period after 1865 are taken from Statistics Norway (1948), Table 126, 241-242; the data on "compensated tonnage" imply that steamships have been multiplied by a factor of 3.6 to account for their higher efficiency.

${ }^{48}$ The data in Brautaset $(2002,261)$ suggest that the annual export of shipping services declined in 30 per cent of the years in the period $1830-1850$, compared with 13.3 per cent in the period 1850-1865. The only years with decline after 1850 were 1857 and 1858, and are thus closely associated with what Hughes 1956, 194 refers to as "the first world-wide commercial crisis in the
} 
century the development changed dramatically. In the period 1850-1875 the growth was both much stronger and more persistent than before.

The average annual growth rates increased from 0.18 per cent 1800-1830, a period with a see-saw pattern of growth and decline, to 3.85 per cent from 1830 to 1850 . In the subsequent 15 years the Norwegian fleet grew at an astonishing 5.75 per cent annually, before falling back to 0.44 per cent in the years up to the turn of the century. The latter stagnation, however, was mitigated by the transformation from sail to steam. In fact, when we take into account the higher productivity of the steamships, the fleet continued to increase, with only a handful of hiccups, until the losses in connection with the First World War. ${ }^{49}$ In terms of "compensated tonnage" — a measure of transport capacity that takes into account the superior efficiency of steam vessels - the average annual growth was 3.7 per cent from 1865 to 1900 . This was a reduction compared to the previous 15 years, but still a relatively large increase and far higher than the growth in the economy in general.

After the removal of political restrictions had "opened up" the international market in the middle of the 20th century, there was a self-sustaining element to the Norwegian shipping industry. Regardless of whether we call this "path dependence" or "tradition," the fact of the matter is that Norway's fleet was very competitive in the international shipping market. It could offer reliable transport at a reasonable price. This was partly explained by the conditions at home: Norwegian shipping enterprises were very competitive in the quest for domestic capital and labour.

In the 1850s, the first decade of this expansive period for Norwegian shipping, additions to the fleet were to a large extent built domestically. The industry had access to "the raw materials and the builders needed to manufacture first-class ships"-particularly on the South Coast. Moreover, "shipbuilding geniuses such as for instance Annanias Dekke in Bergen" competed among the leading shipbuilders internationally. ${ }^{50}$ The demand for ships outstripped the local supply and, from the 1860 s

history of modern capitalism.” For the Norwegian dimension of this crisis, see Eitrheim et al. (2016, 156-164).

${ }^{49}$ Estimates are average annual compound gross rates based on net registered tonnage; for information on the data, see Fig. 2.3.

${ }^{50}$ Egeland (1930, 31). 


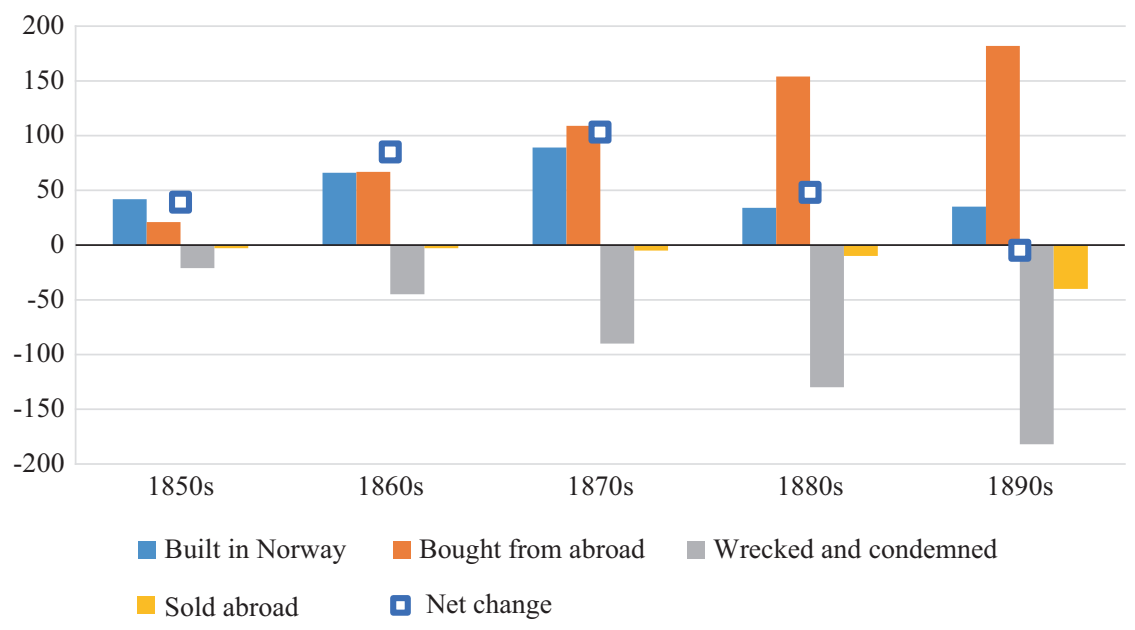

Fig. 2.4 Average annual fleet increase and decrease by source, 1851-1900, 1000 net register tons. (Source: Statistics Norway (1968), Table 176, 364-365. See footnote)

onwards, a larger share of the new ships was imported. ${ }^{51}$ One reason for the increasing imports was the fact that the authorities during the 1850 s twice reduced, and then finally removed, the "naturalization levy," a tax on ships bought abroad. ${ }^{52}$ This tax had been to the benefit of shipbuilders, but to the detriment of shipowners. ${ }^{53}$ The other main reason for the growth was that shipowners in other countries - in particular the UKmodernized their fleets by investing in steam tonnage. Consequently, a large number of relatively inexpensive second-hand sailing ships were for sale in the international market in the last decades of the 19th century.

Figure 2.4 illustrates the sources of the Norwegian fleet growth. ${ }^{54}$ The figure reveals that although more than half of the tonnage added in the

\footnotetext{
${ }^{51}$ Statistics Norway $(1968,364)$.

${ }^{52}$ Hodne (1980, 167).

${ }^{53}$ Though, at this time, there was a much larger overlap between these groups than today.

${ }^{54}$ Figure 2.4: Statistics Norway (1968), Table 176, 364-365. Net increase and decrease based on individual columns, which differ from the aggregate figures given in the original source. Supplemented by information from Statistics Norway 1949, Table 129. The original source points out that the figures for the early period are "incomplete, due especially to difficulties in securing exact data as to the great number of vessels not registered." The "unregistered" vessels are sailing
} 
period 1850-1870 was bought from abroad, there was at the same time a strong increase in shipbuilding within Norway. The production peaked in 1875, when more than 264 ships, amounting to around 75,000 net register tons, were built. ${ }^{55}$

Fritz Hodne refers to shipping as "the leading sector" in Norwegian economic development in the period after the Navigation Acts were repealed. With its impressive growth rates, the shipping industry clearly outshone other large sectors. According to Hodne's calculations, shipping investments amounted to around 30 per cent of total gross investments in the quarter century after $1850 .{ }^{56}$ As pointed out above, the main driver behind the demand increase was found abroad-more than threequarters of the growth came from transport between foreign ports, and was thus totally independent of Norway's own transport demand. ${ }^{57}$

Still, conditions within Norway complemented its international development, facilitating the rapid growth of the fleet. There are two main reasons for the attractiveness of shipping employment and investments in Norway. First, the alternative employment and investment opportunities were limited. In the 19th century, Norway did not have large exploitable reserves of coal or other minerals. Moreover, the modest purchasing power among domestic consumers and the long distance to larger markets in Europe implied that the conditions for large-scale manufacturing production were relatively unfavourable. Nascent textile and mechanical engineering industries notwithstanding, Norway never went through industrial revolutions of the British or German kind. ${ }^{58}$

When life expectancy increased in the second half of the 19th century, migration became an important safety valve that checked population

ships smaller than 50 net register tons and steam and motor vessels smaller than 25 net register tons. This poses larger problems for the data on the number of ships, than for the tonnage figures, as the majority of the unregistered ships were small vessels.

${ }^{55}$ Based on the number of ships, production peaked in the second half of the 1860 s. However, due to increasing average size, in tonnage terms the first half of the 1870 s saw the largest production; see Fig. 2.4 for information on the statistics.

${ }^{56}$ Hodne $(1981,27)$. Based on slightly different data and methods from what we used above, Hodne calculates the annual growth rate of the fleet to be 6.8 per cent for the period 1850-1875.

${ }^{57}$ Calculated on the basis of ton-miles data in Brautaset (2002), 259.

${ }^{58}$ For a good overview of the discussion of Norway's industrial breakthrough, see Basberg (2006, 4-7). 
growth. Around 800,000 Norwegians left for the new world in the period 1830-1920 - in percentage terms, only Ireland had a higher outflow of emigrants. ${ }^{59}$ The effect on Norwegian wages and living standards was strongly positive. The existing arable land would not have been able to sustain the increased numbers and the conditions were not favourable for a mass exodus into the secondary sector. With few domestic opportunities, employment at sea was another manner in which the surplus labour force could be utilized. Sometimes migration and seamanship was combined; Norwegian sailors had "gained such a reputation for ability and good conduct that they were eagerly sought by American captains." 60

In a discussion of subsidies to shipping in the US Congress, it was pointed out that " $[\mathrm{n}]$ ecessity compels and tradition invites the Norwegians to become seamen." According to the Americans, "[Norwegian] capital and labor naturally turn to the sea, and laws which in the United States would be restrictive, in Norway are merely the affirmation of local customs. Thus the law requiring three-fourths of the crews of Norwegian ships to be Norwegian imposes no restraint on the growth of Norwegian shipping, while a similar law in the United States would virtually drive all our ships in foreign trade to foreign flags." ${ }^{61}$

The demographic development ensured an ample supply of seamen. A combination of local resources and institutions facilitated the investment in ships on which they could sail. ${ }^{62}$ The early dominance of Norwegianbuilt ships was related to the type of organization-partsrederiet [the part ownership] — where local communities pooled their resources to invest in ships. The part ownerships were an ingenious way of raising investment capital for new shipping capacity, even though access to traditional equity and credit was limited. On the South Coast, "the forest, the wooden ship and the part ownership" were considered "the God-given foundation for shipping." ${ }^{63}$ However, this organizational form also had its drawbacks, as it made long-term investment difficult.

\footnotetext{
${ }^{59}$ O'Rourke and Williamson $(1999,122)$.

${ }^{60}$ Gjerset $(1933,63)$.

${ }^{61}$ The original text says "compels." US Senate, 1922, To amend Merchant marine act of 1920: Joint hearings before the Committee on Commerce, Washington: Government Printing Office.

${ }^{62}$ Before the strong growth of the country's own fleet, many Norwegian sailors had found employment on, for instance, Dutch ships;

${ }^{63}$ Tønnesen $(1951,80)$.
} 
In the early expansionary phase, in the 1850 s, when the majority of the vessels were built in Norway, most new ships were constructed as "a cooperation between the builder, the timber merchant, the captain and the supplier. Farmers who delivered wood from their forests, craftsmen and ships chandlers thus participated with a smaller or larger part based on their deliveries and resources. The out-of-pocket expenses thus became very limited." ${ }^{4}$ Shipping was a potluck business, where the owners contributed, often in kind, with what they had. The legal regime made the use of ships as collateral impossible. Although it was possible to borrow money on the basis of individual parts, it was also common to use dwellings, farms or friends and family as guarantee.

The part ownerships were "projects," where the investment horizon was the lifetime of the vessel. Profits were paid out at regular intervals or as and when they occurred-sometimes after every individual voyage. When the ship was sold, scrapped or lost, any remaining funds were paid out to the part owners according to their share of the investment. The project then ended - the business was over. Investors reduced their risks by diversifying and participating in several vessels, and it was easy to reinvest the funds in new ship parts.

A combination of tradition and agreements — within the boundaries of a very limited legal framework - served to regulate the part ownerships. According to Sjøloven av 1860 [the Maritime Act] the vessel could only be insured if all part owners agreed. If the ship was not fully insured-or not insured at all - it was possible for individual owners to insure their parts.

In order to avoid costly foreign insurance arrangements, mutual associations were established along the coast. From a slow and late start in the second half of the 1830 s, by the middle of the century around threequarters of the merchant marine had been insured in mutual associations - "an astonishing breakthrough" for a type of organization that was new in a Norwegian setting. ${ }^{65}$ It has been claimed that the efficient and low-cost insurance arrangements helped the Norwegian competitiveness. ${ }^{66}$ The high market share remained well into the 1890 s, when a larger

\footnotetext{
${ }^{64}$ Seland $(1959,143)$.

${ }^{65}$ Espeli $(2010,49)$.

${ }^{66}$ Espeli (2010).
} 
share of the ships_-in particular sailing vessels_-began to sail without hull insurance.

As shipping played such an important role in local communities along the coast, "surprisingly large parts of the population became mobilized in the accumulation process." ${ }^{\prime 67}$ Due to the in-kind nature of part of the investment, it would not have been possible to raise the same amount of capital for other purposes. The integration of shipping - and the other main export sectors, fish and forest products-in the domestic economy, implied that the export-led economic growth did not lead to an enclave-like structure of the kind seen in many developing economies, in particular those based on plantation crops and mining. Rather, the close integration created feedback-loops that strengthened the economic development. An analysis from the turn of the century concludes that slightly less than 6 per cent of the Norwegian population directly or indirectly depended upon shipping for their livelihoods, compared with 1.5 per cent in Denmark and 1.3 per cent in the case of Sweden. ${ }^{68}$

Shipping's role as a leading force with regard to employment and investment reflected the competitive advantages that the Norwegians had built up in international shipping-advantages that had become "unshackled" by the repeal of the Navigation Acts. Over the previous centuries, the Norwegians had developed skills that made them "formidable competitors" in the international shipping market; "The Norwegians are born shipowners and have developed the shipping industry for its own sake to a degree that is rare among Continental peoples," according to a British observer. ${ }^{69}$

The typical Norwegian ship in the second half of the 19th century was "the never-tiring tramp, which continually scours the Seven Seas in search of charters, loading from one port to another, and never knowing where she may have to sail for next, picking up cargo here and running light there, figuring frequently in the overdue list, and sometimes turning up after she has been posted missing, but always returning to her home port,

\footnotetext{
${ }^{67}$ Bergh et al. $(1983,113)$.

${ }^{68} \operatorname{Kiær}(1900,436)$.

${ }^{69}$ Fayle (1933 [2006], 272).
} 
battered and weather-beaten, ready to sail again after an overhaul in dry dock and the renewal of her certificate of character." 70

Shipping was hard work, and it was risky. In the last part of the 19th century, as the sailing ships got older, loss rates increased tremendously. Still, this dangerous, but profitable, activity lay the foundation for the Norwegian position as a major maritime nation. By the middle of the 19th century, shipping had become a crucial economic activity all along the coast in the southern part of Norway. Although the sector often had to share its key role-some places with forestry, other places with fishing or whaling - it was an integral part of the market economy, providing employment, investment opportunities and services. By the turn of the century, Norway had 10 ships for every factory.

\section{Norwegian Maritime Culture}

So far, we have looked at the roles of geography and history-two relatively tangible concepts. The final reason that can explain how and why Norway managed to build up and maintain a dominant position in international shipping is more difficult to pin down; culture. Sometimes, "culture" is considered the refuge of the scoundrel; the trump card which historians and social scientists refer to when they have run out of arguments and facts. However, culture "remains our default term for covering the relation between forms and social processes." 71 It may be hard to define, but we usually know what it is...

In our context, the term "culture" contains two important dimensions. The first is what we can refer to as "maritime culture," which refers to the traditions, structures and practices that make Norwegians see themselves as a sea-going people and the sea as a natural extension of the land. When an 80-year-old captain explains that he did "his best" at sea, because he "wanted to assert Norway's honour as a sea-going nation with traditions back to the era of the sagas," that is the maritime culture talking- "the spirit of the sea." 72

\footnotetext{
${ }^{70}$ An early 20th century presentation of tramp shipping quoted in Harlaftis and Theotokas (2004, 219).

${ }^{71}$ Halperin $(2012,133)$.

${ }^{72}$ Worm-Müller (1951, 487).
} 
The second element is "Norwegian culture," which covers the manner in which society was organized, including the norms and values that gave Norwegian shipowners a competitive advantage internationally. Specifically, in most coastal communities in southern Norway, work on and investments in ships was an important activity. ${ }^{73}$ As the legal infrastructure was limited, the concept of trust, regulated by and integrated in informal local networks, became important.

The cultural aspect, and here we are mainly talking about the maritime element, was clearly linked to the geographical and historical foundations. The influence from the surroundings, and in particular the visibility of shipping, enticed young males to see a career at sea as the embodiment of the ultimate dream. Norway was the land of the Vikings. Vikings went to sea. The sea began just outside the window. However, the culture also changed across time, hence "when the sailing ship era ended, a distinctive culture died out." ${ }^{\prime 4}$ The transition to steam changed the life of most seamen both at sea and in port, but it did not change the perception of Norway as a maritime nation and Norwegian men as a seafaring tribe.

The mystery and attraction of the sea is a staple of seamen's memoirs: "I had my heart set on going to sea [...] my greatest delight was to roam the waterfront and watch and listen to the sailors at their work in the ships' rigging, and their singing, hoisting and bending sails to the yards and spars, preparatory to the setting out for voyages to far places. Here was romance, here was life." 75 With a starting point such as this, it is perhaps not surprising that the boy in question ends up as a captain.

Another sailor rued "the sad day, when the fever of the sea no longer makes the pulse of the youth beat faster and no longer stirs their longing for new experiences and new, always new, horizons." 76 Of course, these

\footnotetext{
${ }^{73}$ In an international perspective, the largest Norwegian cities at the start of the 20th century, Kristiania and Bergen, clearly had small-city features; among the bourgeoise-the merchants and shipowners-everybody knew everybody. In 1900, the population of Inner London was three times as large as that of Norway.

${ }^{74}$ Tønnesen $(1951,165)$.

${ }^{75}$ Bratrud $(1961,8)$.

${ }^{76}$ Rasmussen $(1952,14)$; see also 36-40. Adolescents with romantic views of seamanship and the call of the sea are found, for instance, in Stamsø (1929), or the interview in Tranøy (1941, 41-43).
} 
seamen's memoirs themselves-with their exoticism and tales of adventures in far-off places_-ensnared new generations of sailors. The difference between domestic docility and adventures abroad was also emphasized by contemporary observers. "The wider horizon, the richer and more varied life abroad, the wonders of art and industry - contrasted with the monotony of life which often prevails in many small communities on the sea-coast - how all these must attract young lads," A.N. Kiær pointed out in his discussion of the "principal causes" behind Norway's standing as a maritime nation. ${ }^{77}$

Many of the seamen's memoirs tell stories of boys escaping impoverished circumstances in Norway, where the food, lodging and modest wages at sea become a means of survival. ${ }^{78}$ For others, sea voyages were a part of the general education. "A custom that was quite common in seafaring towns, in particular in Bergen," was a period at sea, reminiscent of the apprentices' Wanderjahre. The bourgeoisie, businessmen and others that were involved in shipping, sent their "sons - with reassuring supervision - on a couple of months' voyage on a cargo ship, fostering maturity and giving experiences at an impressionable age." The voyages taught him (for it was invariably a boy) about "foreign places and peoples [...] and international trade and business." 79

The allure of the sea around the turn of the century, when the sailing ships were still frequent guests in Norwegian ports, is self-evident. But "the call of the sea" kept its power well into the second half of the 20th century. For many of those growing up in the 1950s and 1960s, a period at sea became an important rite of passage, a gap year activity that marked the transition to adult life. For many young sailors there was "one common element: The dream of seeing and experiencing the wide world that one otherwise had only read or heard about." 80

\footnotetext{
${ }^{77}$ Kiær $(1893,363)$. Kiær's reasoning, "How can these young Viking lads but long for the time when they, too, are permitted to cross the sea into the wide, wide world?", is almost poetic in its prose. The fact that the article was published in The Journal of Political Economy, a periodical that both then and now ranks among the most important in economics, illustrates the drastic transformation of economics as a branch of science. Today, authors in the journal argue by equation, not by interpretation; by positivism, not by prose.

${ }^{78}$ See for instance Tønnessen (1996), as an example of someone leaving for the sea out of necessity.

${ }^{79}$ Meidell (1968).

${ }^{80}$ Pettersen and Brundtland $(2002,72)$.
} 
For the 19th and the first part of the 20th century, shipping was the most important lifeline to large parts of the world. Exotic cultures did not have many inroads into Norwegian society at this time; the country had a modest military and colonial presence abroad, and mobility was slow and limited for most people. ${ }^{81}$ In the days before low-cost plane tickets, mass tourism and public broadcasting, information about distant places came primarily via seamen, missionaries, emigrants and a small number of merchants and adventurers.

The written seamen's memoirs were but a small part of the transmission of life at sea and abroad. More important were the gifts that the sailors brought home and the "taste of the sea" that they gave by means of stories, tall tales and songs. Shanties (work songs) and other seamen's songs were important culture bearers, anchored in the coastal communities, where young boys heard about Pensacola and Pernambuc — not Paris or Berlin..$^{82}$ Onboard the ships, the shanties had a function-they were used to coordinate the sailors' work. Ashore, their call-and-response could create a sense of community, bringing the sea back to the shore and stirring the adventurousness of those at home.

In seafarers' songs and shanties, sailors are portrayed as a strange combination of carefree and melancholic; without a care in the world, but longing for home. Strong drink and hard work are among the main themes, as well as love and loss. Rio de Janeiro, Hamburg, New York, the East Indies — foreign places filled with young girls whose main desire was to meet a "Norwegian sailor boy." The songs themselves reveal the global character of shipping; the chorus was often "imported"—-sung in "a sailor-English that was almost as international as the melody." ${ }^{83}$

The transmission of seamen's culture through stories and songs was informal, but the country's sailors played a more formal role as cultural ambassadors as well. Several Norwegian museums built up their ethnographic

\footnotetext{
${ }^{81}$ This was an era of great contrasts. Many people never left their home town or village, those who did often went far- to the other side of the world.

82 "Pernambuc" refers to Pernambuco, in the north-eastern part of Brazil, the 18th most visited destination in the Lloyd's List data set with almost 1 per cent of the port calls. The contraction makes the word rhyme with the Norwegian sukk [sigh], which the sailor emits when he thinks of Norway. For the full lyrics to "Sing Sally Oh", a modern version based on Wergeland's poem about the Preciosa, see Brochman (1937, 28-32).
}

${ }^{83}$ Brochmann $(1937,39)$. 
collection on the basis of what sailors brought home from abroad; they were instructed by the museums about which pictures and artefacts that would be interesting. ${ }^{84}$ Foreign memorabilia—souvenirs, novelties, mementos and exotic objects-were common in the homes of sailors and their families. The sea was the path to the rest of the world; the seamen were the guides.

The "maritime culture" clearly made its mark on Norway. But how did "Norwegian culture" influence the country's foray into shipping?

In his analysis of Norwegian culture and society, the anthropologist Arne Martin Klausen identifies four features that characterize the country. Two of these, in particular, may have been important for the expansion of the country's shipping industry. The first is the fact that Norway can be characterized as a "small-scale society with a large degree of informal social control." This was particularly relevant for the many enterprises in towns and smaller cities along the coast, where the informal framework facilitated investment and partnerships. The second characteristic element of the Norwegian culture and society is the fact that the ideology of equality (egalitarianism) has a particularly strong position. ${ }^{85}$

The small transparent communities encouraged the dispersed type of ownership that characterized the Norwegian partsrederier. In the absence of a clearly-defined legal framework, the strong social control and the threat of social exclusion created a quasi-institutional legality. The shortcomings of the public legal system were thus neutralized. In this respect, the experience is not very different from that seen within some fringe religious movements, such as for instance Quakers. There was an awful lot of trust and good faith involved in the manner in which shipping investments were organized and business was conducted.

Joint investments and other interactions had the properties of a "repeated game"; you could not cheat your fellow shipowners, because you would have to look them in the eye when you met them in church or on the street. Moreover, you needed them to trust you with their resources in the future as well. Of course, not all business ventures followed this idealized model, but the "trust" aspect of Norwegian culture and society

\footnotetext{
${ }^{84}$ Austbø (2012). Missionaries made up the other significant group of collectors.

${ }^{85}$ Klausen (1999, 32-33) also emphasizes the strong Norwegian welfare state and the strong presence of the periphery in the political system, but these two features are not relevant in a 19th century setting.
} 
clearly enabled and encouraged capital formation on a scale that would otherwise have been unthinkable.

When more modern types of incorporation, for instance limited liability companies, replaced the part ownership, the "old" mechanisms continued to play an important role. As we shall see, this cooperative spirit-between investors, but also between for instance shipowners, banks and insurance companies - continued to be relevant into the 20th century. The joint projects—-sometimes with unlimited responsibilitywere beneficial for all parties when the markets were going up and there was a need to pool resources to remain competitive, but they also meant that problems spread rapidly when the demand conditions deteriorated.

Trust between partners and other business relations-both before and after the existence of a more formal legal framework-was a Norwegian "character trait" that facilitated the country's shipping investment. Other results of this trust-for instance the low insurance premia in local associations-gave Norwegian owners a cost advantage that improved their competitiveness. So, the social control seen in the coastal communities, through its effect on investment and profits, undoubtedly helped build up Norway, the maritime nation.

The egalitarian nature of Norwegian society may also have boosted the maritime presence. Throughout the 19th century Norway was a society characterized by the absence of nobility, and with class differences that in an international perspective can be considered relatively low. For sure, Norway was far from an egalitarian paradise where paupers and princes went hand in hand. However, the fact that there were relatively weak class distinctions affected the development of a maritime Norway positively. For instance, the willingness to accept investments from all parts of the population - without discrimination—enabled capital formation.

"Practically all and sundry were a shipowner [in the 1860s]. Everyone that had saved some money usually did not give up until they had invested it in a part of a ship." ${ }^{\prime 6}$ As ships became larger and more expensive, the number of parts per ship increased-from 4 or 16 to 64 or 100. After around 1890 the number of part owners increased, with many "new names," including "common people." Managing owners approached

\footnotetext{
${ }^{86}$ Vigeland (1943, 170).
} 
"friends and enemies, the learned and the unlearned, the tailor and the shoemaker [...] until the sought-after 100/100 parts were safely anchored in larger and smaller portions of people's savings, from all of the city and from all walks of life." 87

The pattern continued into the new century, when the organizational form gradually shifted from partnerships to limited liability companies. The shipowner Olav Ditlev-Simonsen, the pater familias of one of the most successful 20th century "shipping dynasties," had ordered a steamship; "it was not like now [1945] that the bank or the yard provided first priority [mortgage]. All of the capital had to be procured at once." For a couple of months Ditlev-Simonsen "travelled the country, like a sales agent for shipping shares." The shares cost NOK1000 each "and 90 per cent of the shareholders were small savers who at most could afford one or a couple of shares each, seldom more than five. They were tailors and shoemakers, bakers and wheelmakers." 88

This notion that everyone- "the clergyman, the doctor, the district recorder, and in particular sailors, merchants, craftsmen, even servant girls" - had invested in shipping, is a generalization that should be modified. ${ }^{89}$ Like investments in general, the majority of the funds came from the wealthiest. Although Olaf Ditlev-Simonsen claims that 90 per cent of the shareholders were small savers, his own company "signed up for a large part." 90 Still, there is little doubt about the fact that the shipping sector was a vehicle for social mobility.

The sailing ships offered careers for hard-working boys; the best and the brightest could rise in the ranks until they were masters themselves. Experience and skills were acquired on-board; along the way, if funds were put aside, the sailor could become investor. Towards the end of his career, when the experienced captain signed off, he would use his knowledge and take over as corresponding owner for one or more ships. Naturally, not everyone managed to reach that far-but the possibility was there. When Ordinary seamen had signed on a couple of times, they

\footnotetext{
${ }^{87}$ Pettersen (1980, 208 and 211).

${ }^{88}$ Ditlev-Simonsen (1945, 79-80).

${ }^{89}$ Due (1909), quoted in Sandvik $(2018,84)$.

${ }^{90}$ Ditlev-Simonsen $(1945,79)$.
} 
became Able seamen, and could progress to Boatswains. Third mates could become Second mates and then First mates. And First mates could become Captains.

The two largest shipping companies in Bergen in 1890 had been established by former captains, and in the subsequent decade a large number of "captain shipowners" established new businesses, sometimes-but not always - in cooperation with clerks from existing shipping company offices. ${ }^{91}$ When the Norwegian Shipowners' Association was established in 1909 , the majority of the founding committee were former captains who had become "managing owners" or sons of captains who had gone ashore and continued their careers as investors and owners. "The captain who ventured his savings on his own vessel - that was once the very basis for the Norwegian merchant marine." 92 And they remembered where they came from. The previously mentioned Olaf Ditlev-Simonsen, who went to sea straight after his confirmation and by the outbreak of the Second World War controlled one of the largest fleets in Norway, called his autobiography En sjøgutt ser tilbake [A seaboy looks back]. ${ }^{93}$

The main task of the managing owners was not unlike that of the captains; to navigate profitably and safely in conditions that were unpredictable and difficult to influence. During the great expansion of Norwegian shipping after 1850 , the managing owner had often in practice been little more than the partners' book-keeper. Many-or most-of the shortterm business decisions were made by a captain who was far away and difficult to instruct. As communication channels improved, commercial decisions about cargoes and trades could more easily be made at home. Former captains could combine their accumulated knowledge of ports and markets, with "ears on the ground" and information from other public and private sources, and then relay their instructions to the ships. Decision-making power moved from the sea to the home port.

\footnotetext{
${ }^{91}$ Pettersen $(1980,205)$.

${ }^{92}$ Aurmark et al. $(1977,79)$ : the heading of the chapter, which deals with contemporary shipping in the 1970s, is called "There is still a room for sailors in the shipowning profession."

${ }^{93}$ Ditlev-Simonsen (1945). At the time of his death, the "seaboy's" group of companies owned 24 ships, amounting to 365,000 dead weight tons, slightly less than 3 per cent of the Norwegian fleet. Interestingly, his son, Halfdan — one of three sons that managed a shipping company — called his own autobiography, published 10 years after his father's, "A shipowner looks back." Here, he points out that "The landlubber-shipowners are in earnest entering Norwegian shipping with the generation to which I belong"; Ditlev-Simonsen $(1954,14)$.
} 


\section{The First Decade of the New Century}

When the 19 th century became the 20th, Norway was not a fully independent nation; the monarch and the foreign policy were shared with Sweden. However, during the 19th century a distinct and separate Norwegian identity had continued to develop; a national-romantic cultural awakening and increasing knowledge and incomes stirred the flame of independence. The differences between Norway and Sweden-and in particular their diverging economic and political interests-became more pronounced. There is no doubt that the Norwegian emergence as a major maritime nation was an important part of the picture that led to the dissolution of the union and Norway's independence in 1905.

Due to the widespread activities of the country's shipping industry, Norwegians had economic interests and engagements all over the world. The country's shipowners thrived under the liberal economic trading regime that emerged in the second half of the 19th century. Sweden, on the other hand, had traditionally a European — rather than global—focus. Moreover, the country's burgeoning manufacturing industry sought protection, rather than liberalism. Thus, "Norwegians and Swedes were divided by basic economic and commercial differences." 94

At this time, consuls - the national representatives abroad-were a crucial element of the mercantile and maritime infrastructure. These consuls were appointed by the Swedes, who were in control of the dual kingdoms' foreign policy. Naturally, they tended to have Swedish interests at heart. Norwegian politicians-led by the cunning Bergen shipowner Christian Michelsen, who was appointed Prime Minister in March 1905-consequently demanded separate Norwegian consuls. This controversy - followed by some clever political manoeuvring - led to the dissolution of the union and proper Norwegian independence in 1905.

Other things remained the same, however. Around the turn of the century, wars continued to create periods of exceptional revenues, while freight rates were depressed and following a long-term declining trend in more peaceful periods. The Second Boer War (1899-1902) enabled "every craft to obtain constant work and at highly remunerative freights,"

\footnotetext{
${ }^{94}$ Leiren $(1975,224)$.
} 
while The Russo-Japanese War (1904-1905) created "an extensive trade in all merchandise, contraband and legal, with both belligerents, and a corresponding demand for tonnage." 95 Both conflicts had a favourable effect on Norwegian shipping revenues. In 1912 and 1913 freight rates improved again, not as a result of war, but due to a business cycle boom. The return from tramp shipping "which for several years had been around 5 per cent of the capital" increased to 25 per cent by $1913 .{ }^{96}$ But the eternal problem with cycles is that after they have gone up, they are bound to go down.

Gunnar Knudsen, president of the Norwegian Shipowners' Association — who was also Prime Minister of Norway-was in a sombre mood when he opened the annual meeting of the association in early July 1914. Although the two previous years had been good, shipping supply was increasing faster than demand and the business cycles were not favourable. According to previous experience, he pointed out, freight rates would remain at a low level for at least three to four years. ${ }^{97}$

He was totally wrong. ${ }^{98}$ Over the next four years, Norwegian shipping companies would see their most profitable period ever, and Norwegian sailors one of their most petrifying.

\section{Bibliography}

\section{E.A.V. Angier (1920) Fifty Years' Freights (London: Fairplay)}

S. Aurmark, O-L. Skundberg \& N. Schjander (1977) Med verden som virkefelt: 18 norske shippingportretter (Oslo: Hjemmet)

A.T. Austbø (2012) 'Sjøfolks medbrakte gjenstander - en problematisk museumskategori?' Tidsskrift for kulturforskning, 11:1, 25-39

B.L. Basberg (2006) 'Patenting and Early Industrialization in Norway, 1860-1914. Was there a Linkage?' Scandinavian Economic History Review, $44: 1,4-21$

\footnotetext{
${ }^{95}$ Angier (1920, 101 and 115).

${ }^{96}$ Petersen $(1949,173)$.

${ }^{97}$ Thowsen $(1983,17)$.

${ }^{98}$ This was not the most faulty prediction that Gunnar Knudsen made that year. During the debate on the King's speech in February 1914, he pointed out that "At present, the political sky, globally, is in fact without clouds to an extent that has not been the case for many years." Norway, Parliament, Stortingsforhandlingene 1914, 17 February, 35.
} 
T. Bergh, T.J. Hanisch, E. Lange \& H.Ø. Pharo (1983) Norge fra u-land til i-land: vekst og utviklingslinjer 1830-1980 (Oslo, Gyldendal)

Å.G. Blom (1977) Folkeviser $i$ arbeidslivet (Oslo: Universitetsforlaget)

O. Bjerkholt \& T. Skoglund (2012) Anders Nicolai Kier - en pioner i nasjonalinntektsberegninger (Oslo: Statistisk Sentralbyrå)

O.M. Bratrud (1961) Beating to Windward: Afloat and Ashore (Seattle: published by the author)

C. Brautaset (2002) 'Norsk eksport 1830-1865 i perspektiv av historiske nasjonalregnskaper', PhD-thesis (Bergen: Norges Handelshøyskole)

C. Brautaset \& S. Tenold (2008) 'Globalisation and Norwegian shipping policy, 1850-2000', Business History, 50:5, 565-582

C. Brautaset \& S. Tenold (2010) 'Lost in Calculation? Norwegian Merchant Shipping in Asia, 1870-1914', in M. Fusaro \& A. Polónia (eds) Maritime History as Global History (St. Johns: IMEHA) 203-222

O.J. Broch (1876) Kongeriget Norge og det norske folk (Kristiania: Steenske Bogtrykkeri)

D. Brochmann (1937) Sjømannsviser (Oslo: Tiden)

O. Ditlev-Simonsen (1945) En sjøgutt ser tilbake (Oslo: Cappelen)

O. Ditlev-Simonsen (1954) En reder ser tilbake (Oslo: Nationaltrykkeriet)

C. Due (1909) Erindringer fra Henrik Ibsens ungdomsàr (Copenhagen: Græbes Bogtrykkeri)

S. Dyrvik (1979) Norsk økonomisk historie 1500-1970, Volume I: 1500-1850 (Bergen: Universitetsforlaget)

J.O. Egeland (1930) 'Norges sjøfart. Hvad den var og hvad den er', in G. Stenersen (ed) Sjømannsboken; sjøfart, hvalfangst, marine: orientering i sjømannskap, veiledning til selvstudium (Oslo: Norsk bibliotekforening) 3-37

$\varnothing$. Eitrheim, J.T. Klovland \& L.F. Øksendal (2016) A Monetary History of Norway, 1816-2016 (Cambridge: Cambridge University Press)

H. Espeli (2010) 'Fortropper for gjensidig skadeforsikring i Norge. Skipsforeningene og brannkassenes gjennombrudd på 1800-tallet: Likheter og forskjeller', Arbok Norsk Maritimt Museum 2010, 47-90

C.E. Fayle (1933) A short history of the world's shipping industry, reprint 2006 (London: Routledge)

P. Figenbaum, E.S. Koren, P. Norseng \& T.L. Nilsen (2009) Verdens fraktemenn (Oslo: Arts Council Norway; The Norwegian Coastal Administration; The Directorate for Cultural Heritage and the Directorate of Fisheries)

J. Glover (1863) 'On the Statistics of Tonnage During the First Decade Under the Navigation Law of 1849', Journal of the Royal Statistical Society of London, XXVI, No. 1 (Mar. 1863) 
K. Gjerset (1933) Norwegian Sailors in American Waters - A Study in the History of Maritime Activity on the Eastern Seaboard (Northfield, Minnesota: Norwegian-American Historical Association)

N. Grieg (1922) Rundt Kap det gode haap: vers fra Sjøen (Oslo: Gyldendal Norsk Forlag)

D.M. Halperin (2012) How to be gay (Cambridge: The Belknap Press of Harvard University Press)

G. Harlaftis \& I. Theotokas (2004) 'European Family Firms in International Business: British and Greek Tramp-Shipping Firms', Business History, 46:2, 219-255

F. Hodne (1980) 'Stortingssalen som markedsplass. Analyse av statens grunnlagsinvesteringer 1840-1914', PhD-thesis (Bergen: Norges Handelshøyskole)

F. Hodne (1981) Norges økonomisk historie 1815-1970 (Oslo: J.W. Cappelens Forlag)

J.R.T. Hughes, (1956) 'The Commercial Crisis of 1857', Oxford Economic Papers, new series, 8:2, 194-222

H.C. Johansen (1992) 'Scandinavian Shipping in the Late Eighteenth Century in a European Perspective', The Economic History Review, 45:3, 479-493

B.E. Johnsen (1993) Han sad i prisonen - sjøfolk i engelsk fangenskap 1807-1814 (Oslo: Universitetsforlaget)

A.N. Kiær (1876-1892) Statistique Internationale Navigation Maritime, Volumes I-IV (Christiania: Le Bureau Central de Statistique du Royuame de Norvége) A.N. Kiær (1893) 'Historical Sketch of the Development of Scandinavian Shipping', The Journal of Political Economy, 1:3, 329-364

A.T. Kiær (1900) "Commerce and shipping" in S. Konow \& K. Fischer (eds) Norway: Official publication of the Paris exhibition 1900 (Kristiania: Aktie-bogtrykkeriet)

A.M. Klausen (1999) Olympic Games as Performance and Public Event: The Case of the XVII Winter Olympic Games in Norway (New York: Berghahn Books)

T.I. Leiren (1975) 'American Press Opinion and Norwegian Independence, 1905', Norwegian-American Studies, 27, 224-242

E. Lie \& H. Roll-Hansen (2001) Faktisk talt - Statistikkens historie i Norge (Oslo: Universitetsforlaget)

S.S. Meidell (1968) 'Sigurd Segelcke Meidell interviewed by Jakob Skarstein', NRK Middagsstunden, 26 August 1968 (Bergen: NRK)

Norges Rederforbunds Sjømannsfond av 1918 (1973) Norske sjømannfond og stiftelser (Oslo: Grøndahl \& Søn) 
K. O'Rourke \& J. Williamson (1999) Globalization and history - The Evolution of a Nineteenth-Century Atlantic Economy (Cambridge: MIT Press)

J. Ojala \& A. Räihä (2017) 'Navigation Acts and the integration of North Baltic shipping in the early nineteenth century', International Journal of Maritime History, 29:1, 26-43

J. Ojala \& S. Tenold (2017) 'Maritime trade and merchant shipping: The shipping/trade-ratio from the 1870s until today', International Journal of Maritime History, 29:4, 838-854

K. Petersen (1949) Norsk dampskipsfart blir en stormakt på verdenshavene (Trondheim: E. Bruns Bokhandels Forlag)

E. Pettersen \& H. Brundtland (2002) Vi som dro til sjøs - Norske sjøfolks opplevelser fra etterkrigstiden (Bergen: Edvard'en Forlag)

L. Pettersen (1980) 'Fra kjøpmannsrederi til selvstendig næring, 1860-1914', Bergen og Sjøfarten III (Bergen: Bergens Rederiforening og Bergens Sjøfartsmuseum)

A.H. Rasmussen (1952) Tatt av havet (Oslo: Cappelen). Published in English as Sea Fever (New York: Crowell, 1952) and (New York: Hastings House, 1960).

P. Sandvik (2018) Nasjonens velstand. Norges økonomiske historie 1800-1940 (Bergen: Vigmostad \& Bjørke AS)

J. Schreiner (1952) 'Review of Den norske sjøfarts historie', Historisk Tidsskrift, 36, 255-295

J. Schreiner (1963) Norsk skipsfart under krig og høykonjunktur, 1914-1920 (Oslo: Norges Rederforbund/Cappelen)

A.M. Schweigaard (1840) Norges Statistik (Christiania: Johan Dahl)

J. Seland (1959) Rederen og skipet. Kristiansand og Mandal fra seil til damp og diesel (Kristiansand: Christiansands Rederforening)

D. Skre (2014) 'Norðvegr - Norway: From Sailing Route to Kingdom', European Review, 2:1, 34-44

T. Stamsø (1929) Yngste jungmann ombord: Fra seilskibenes dager (Oslo: Damm) Statistics Norway (1902a) Statistisk aarbog for kongeriget Norge 1902 (Kristiania: Det Statistiske Centralbureau/H. Aschehoug \& Co.)

Statistics Norway (1902b) Tabeller vedkommende Norges skibsfart i året 1900 (Kristiania: Det Statistiske Centralbureau/H. Aschehoug \& Co.)

Statistics Norway (1948) Statistiske oversikter 1948 (Oslo: Statistiske Sentralbyrå) Statistics Norway (1968) Historisk Statistikk 1968 (Oslo: Statistisk Sentralbyrå) Statistics Norway (2015) Minifacts about Norway (Oslo: Statistics Norway for the Norwegian Minsitry of Foreign Affairs) 
The Norwegian Joint Committee on International Social Policy (1959) Norway and her sailors: A survey of social legislation (Oslo: The Norwegian Joint Committee on International Social Policy)

A. Thowsen (1983) 'Vekst og strukturendringer i krisetider 1914-1939', Bergen og Sjøfarten IV (Bergen: Bergens Rederiforening og Bergens Sjøfartsmuseum) J.B. Thue (1980) 'Skipsfart og kjøpmannskap, 1800-1860', Bergen og Sjøfarten II (Bergen: Bergens Rederiforening og Bergens Sjøfartsmuseum)

S. Tveite (1965) 'Framgangen for norsk skipsfart etter 1690', Sjøfartshistorisk Årbok 1965 (Bergen: Bergens Rederiforening og Bergens Sjøfartsmuseum) $58-90$

J.N. Tønnessen (1951) 'Fra klipperen til motorskipet', in J.S. Worm-Müller (ed) Den norske sjøfarts historie: Fra de aldste tider til vore dager, 2:3 (Oslo: J.W. Cappelens Forlag) 1-222

M. Tønnessen (1996) Førstereisgutten (Stavanger: published by the author)

N.P. Vigeland (1943) Norsk seilskipsfart erobrer verdenshavene (Trondheim: E. Bruns Bokhandels Forlag)

J.S. Worm-Müller (ed) (1951) Den norske sjøfarts historie: Fra de aldste tider til vore dager, 2:3 (Oslo: J.W. Cappelens Forlag)

Open Access This chapter is licensed under the terms of the Creative Commons Attribution-NonCommercial-NoDerivatives 4.0 International License (http:// creativecommons.org/licenses/by-nc-nd/4.0/), which permits any noncommercial use, sharing, distribution and reproduction in any medium or format, as long as you give appropriate credit to the original author(s) and the source, provide a link to the Creative Commons license and indicate if you modified the licensed material. You do not have permission under this license to share adapted material derived from this chapter or parts of it.

The images or other third party material in this chapter are included in the chapter's Creative Commons license, unless indicated otherwise in a credit line to the material. If material is not included in the chapter's Creative Commons license and your intended use is not permitted by statutory regulation or exceeds the permitted use, you will need to obtain permission directly from the copyright holder.

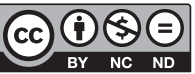

